\title{
Assessing the Effect of Agriculture Sub-sectors on the Gambia's Economic Growth Using Time Series Econometric Models
}

\author{
Fatou Jobarteh ${ }^{1}$, Majige Selemani ${ }^{2, ~ * ~}$ \\ ${ }^{1}$ The Gambia National Bureau of Statistics, Kanifing Institutional Layout, Greater Banjul, The Gambia \\ ${ }^{2}$ Department of Research, Bank of Tanzania, Dar es Salaam, Tanzania
}

Email address:

majiges@yahoo.com (M. Selemani)

${ }^{*}$ Corresponding author

To cite this article:

Fatou Jobarteh, Majige Selemani. Assessing the Effect of Agriculture Sub-sectors on the Gambia's Economic Growth Using Time Series Econometric Models. International Journal of Agricultural Economics. Vol. 5, No. 4, 2020, pp. 142-149. doi: 10.11648/j.ijae.20200504.17

Received: July 1, 2020; Accepted: July 21, 2020; Published: August 19, 2020

\begin{abstract}
The study aimed to assess the contribution of agriculture sub-sectors on the economic growth of The Gambia. The study used time series data obtained from The Gambia Bureau of Statistics for the period from 2004 to 2016. Variables included: Economic growth, Crops, Livestock, Fisheries and Forestry. Denton's method of disaggregation was used to convert annual data into quarterly series. Auto Regressive Distributed Lag model of the co-integrating vector was re-parameterized into Error Correction Model and used to assess the effect of the study variables to the economic growth. The results reveal that crops and fisheries sub-sectors have strong positive effect on economic growth in the long-run while crops and livestock subsector have positive effect in the short run to economic growth in first lag. The study concludes that agriculture sub-sectors influence economic growth in The Gambia. Therefore, the study recommends that massive attention and investments be directed to the agriculture sector for more economic expansion.
\end{abstract}

Keywords: Auto Regressive Distributed Lag Model, Economic Growth, Agriculture Sub-sectors

\section{Introduction}

Globally, agriculture sector acts as the catalyst that accelerates the pace of structural transformation and diversification of the economy, it serves as import substituting sector, providing ready market for raw materials and intermediate goods [1]. More than half of the people living in Africa depends on agriculture for all or part of their livelihood. Based on this premise, fostering agricultural growth increase income and generally improve the living conditions of more than half of Africans. Boosting the income and consumption of people working in agriculture sector is the most effective method for the growth of the rest of the economy [2].

The Gambia is primarily dominated by agricultural activities with about 70 percent of the population depending on agriculture for food and cash income [3]. However, the agriculture sector in The Gambia is characterized with low budgetary allocation, low yields, and low level of inputs and limited areas under cultivation. This is because farmers' depends on mono-cultural economy and the subsistence method of farming [4]. Farmers in The Gambia generally practice mixed farming of which crops accounts for a greater portion of the production. The sector had been declining for the past two and half decades account for several factors including poor rainfall distribution, weak marketing infrastructure, lack of access to credit and a limited resource base [5].

In light of the challenges in agriculture productivity, the potential contribution of agriculture sub-sectors to economic growth is a subject of much controversy among development economists [6]. Economic growth in The Gambia continue to oscillate substantially over the years with a rapid increase in growth of 5.5 percent in 2000 and a drastic decline to 1.6 percent in 2016 [7] and rose to 7.2 percent in 2018 [8]. This was driven by a recovery in agriculture, tourism, 
construction, and trade. Historically, the root of the crises of The Gambian economy lies in the negligence of the agriculture sector by the Government.

The Gambia has witnessed strong economic growth for some time now, averaging about 6.6 percent real annual GDP growth for 2018. The role of sectoral agriculture contributions to the economic growth still remain unclear. Therefore, this study assesses the effect of agriculture subsectors to the economic growth of The Gambia.

\section{Methods}

\subsection{Study Area and Study Design}

The analysis of this study is based on the Republic of The Gambia data. The country located in West Africa surrounded by Senegal on the northern, eastern and southern sides. The Gambia has an estimated land area of about $11,000 \mathrm{~km}^{2}$. This area makes it the smallest country in West Africa with a total population of $1,857,181$ persons of which 49.2 percent are males and 50.8 percent are females according to the Population and Housing Census [9].

This study used secondary data obtained from The Gambia Bureau of Statistics (GBoS). The time series data are observations of the value additions of the Gross Domestic Product estimates spanning from first quarter of 2004 to fourth quarter of 2016. All data were measured in monetary terms-US dollar for easy comparison with similar studies.

\subsection{Data Processing and Analysis}

The data were analyzed using STATA software version 14 and EViews10SV. The variables were obtained in annual frequencies (2004-2016) from the source and converted to quarterly frequencies. Consequently, the Denton's technique of disaggregation was applied to convert the annual series of the variables into quarterly frequencies [10]. In addition, the series span from the first quarter of 2004 to fourth quarter of 2016 , this gave a total of 52 observations.

Variables included in the analysis were Gross Domestic Product (GDP) as outcome variable used as a proxy to economic growth in real terms. The agriculture sub-sectors include crops, livestock, fisheries and forestry were used as independent variables.

The study employed time series analysis to investigate the effect of Agriculture sub-sectors to the economic growth in The Gambia. The study used Augmented Dickey-Fuller (ADF) for unit root test of stationarity and the Auto Regressive Distributed Lag (ARDL) technique for estimating the long-run multipliers and short-run dynamics of the studied variables. The maximum lag lengths selection was chosen using lag length criteria tests such as Likelihood Ratio Test Statistics (LR), Final Prediction Error (FPE), Akaike Information Criterion (AIC), Schwarz Information Criterion (SIC) and Hennan-Quinn Information Criterion (HQIC). Granger causality test was also applied with respect to econometric procedures.

\subsection{Model Specification}

The analysis utilized the Ordinary Least Square (OLS) Method to estimate the parameters in a Multiple Linear Regression fashion. In order to achieve the objective of the study the model was fitted to assess the contribution and relationship between the variables of the study by employing ARDL econometric technique using the function and regression model given by;

$$
R G D P_{t}=\mathrm{f}\left(\text { CoP }_{t}, \text { LiveS }_{t} \text { FisH } \text { FoR }_{t}\right)
$$

Where $R G D P_{t}$ Real Gross Domestic Product at time t,

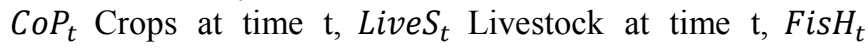
Fisheries at time $\mathrm{t}$, and $\mathrm{FoR}_{t}$ Forest at time t.

The ARDL framework of cointegration or Bound Cointegration Technique was used to estimate both the longrun and short-run components simultaneously. ARDL cointegration technique was preferable in this analysis because it deals with variables that are integrated into different order, I(0), I(1) or combination of both [11], [12]. The basic ARDL model is of the following general form;

$$
\Delta \ln y_{t}=\alpha_{0 y}+\sum_{i=1}^{p} b_{i y} \Delta \ln y_{t-1}+\sum_{i=1}^{q} c_{i y} \Delta \ln x_{t-1}+\lambda_{1 y} \ln y_{t-1}+\lambda_{2 y} \ln x_{t-1}+\varepsilon_{1 t}
$$

Where; $\Delta$ is the difference operator, $y_{t}$ is the log of dependent variable, $x_{t}$ is the $\log$ of independent variable, $p$ and $\mathrm{q}$ are the optimal lag lengths, and $\varepsilon_{1 t}$ is the serially independent random errors with mean zero and finite covariance matrix.

The optimal lag-length incorporated into the models of the study was based on an automatic selection determined by the lowest value specified by the Akaike Information Criterion (AIC) in its selection. The AIC is a powerful criterion to consider in the study as compared to other standard criteria because of its significance in the sample size of not more than 60 observations [13]. The lower AIC value was used to detect the suitable lag used in the model of the study.
ARDL bound test was adopted in this study to identify the co-integrating vector(s) between variables under consideration. If one co-integrating vector is identified, the ARDL model of the co-integrating vector is re-parameterized into Error Correction Model (ECM) and result from the cointegrating vector of ARDL model gives both long run multipliers and short-run dynamics of the variables in a single model [11]. The existence of a long-run relationship in the study was detected through the joint Wald test (F-statistic) when the F-statistic exceeds the critical value bound.

The existence of cointegration among the variables suggests that there must be Granger causality among the variables in at least one direction [14]. Granger causality test 
in Error Correction Model (ECM) framework by [15] was applied in order to identify the direction of the causality between the dependent and independent variables of the study. This was important because, an ECM distinguishes between both the short-run and long-run Granger causality.
In this study, the joint causality of short-run relationship was tested to check for joint significance of the variables. A general specification of the Granger causality test in the context of this study for a model is expressed as follows:

$$
\begin{aligned}
& \Delta \operatorname{InRGDP} P_{t}=\beta_{1}+\sum_{i=1}^{n} \phi_{1 i} \Delta \operatorname{InRGDP}+\sum_{i=1}^{n} \varphi_{1 i} \Delta \operatorname{In} \operatorname{Cop}_{t-1}+\sum_{i=1}^{n} \theta_{1 i} \Delta \text { InLiveS }{ }_{t-1} \\
& +\sum_{i=1}^{n} \delta_{1 i} \Delta \operatorname{InFis} H_{t-1}+\sum_{i=1}^{n} \psi_{1 i} \Delta \operatorname{InFoR_{t-1}}+\chi_{1} E C T_{t-1}+\varepsilon_{1 t}
\end{aligned}
$$

Several residual diagnostic and stability tests proposed by [16] were conducted in the analysis. This includes: Breusch Godfrey test for serial correlation, Breusch-Pagan Lagrange Multiplier test for heteroscedasticity, Jarque-Bera test for goodness of fit and Ramsey Residual Error Specification Error Test (RESET) was employed to ensure that the models are correctly specified. Furthermore, the Cumulative Sum (CUSUM) and Cumulative Sum of Squares (CUSUMQ) tests which are based on recursive residuals were used in testing the stability of the models at 5 percent level of significance. The tests evaluate the parameter stability in the error correction model by testing the constancy of the short-run coefficients over the study period.

\subsection{Ethical Considerations}

This study was approved by Eastern Africa Statistical Training Centre (EASTC). The ethical clearance was approved for Master degree research. Confidentiality, anonymity and privacy were also considered.

\section{Results and Discussion of the Findings}

Table 1 presents the summary statistics of the variables used in the analysis with a total of 52 observations for each variable from first quarter of 2004 to fourth quarter of 2016. The results indicate all variables in the analysis exhibit a normal skewness with the exception of Livestock variable (0.73) which was positively skewed with higher values above their samples averages.

Prior to testing for cointegration, the first step conducted was to examine data stationarity, and consequently the existence of a unit root, by using the Augmented Dickey Fuller (ADF) test. Table 2 presents ADF Unit Root test for all the study variables. The results in Table 2 indicate that at level and first difference the equation with only intercept; Livestock and Fisheries were stationary at level. Whereas the rest of the variables; Real Gross Domestic Product, Crops and Forestry attained stationary by first level of differencing. On that basis, the null hypothesis of non-stationary was rejected at 5 percent significance level and it is safe to conclude that the series are all stationary.

Table 1. Descriptive Statistics of Variables in 000 's of US Dollars.

\begin{tabular}{llllll}
\hline Variables Mean & & Minimum & Maximum & Std. Dev & Skewness \\
\hline lnRGDP & 5.21 & 5.14 & 5.34 & 0.06 & 0.42 \\
lnCrops & 4.27 & 4.01 & 4.55 & 0.17 & 0.09 \\
lnLivestock & 4.14 & 4.07 & 4.29 & 0.06 & 0.73 \\
lnFisheries & 3.50 & 3.40 & 3.65 & 0.07 & 0.32 \\
lnForest & 2.96 & 2.88 & 3.09 & 0.06 & 0.05 \\
Observations & 52 & 52 & 52 & 52 & 52 \\
\hline
\end{tabular}

\begin{tabular}{|c|c|c|c|c|c|}
\hline \multirow{2}{*}{ Variable } & \multirow{2}{*}{ Order of Integration } & \multicolumn{2}{|l|}{ Intercept Only } & \multicolumn{2}{|l|}{ Trend and Intercept } \\
\hline & & ADF-Test Statistics & Critical Value at $5 \%$ & ADF-Test Statistics & Critical Value at $5 \%$ \\
\hline \multirow{2}{*}{$\ln (\mathrm{RGDP})$} & $\mathrm{I}(0)$ & -2.622 & -2.930 & -3.005 & -3.500 \\
\hline & $\mathrm{I}(1)$ & $-4.472 * *$ & -2.601 & $-4.843 * *$ & -3.504 \\
\hline \multirow{2}{*}{$\ln (\mathrm{Cop})$} & $\mathrm{I}(0)$ & -2.530 & -2.930 & $-3.604 * *$ & -3.500 \\
\hline & $\mathrm{I}(1)$ & $-5.084 * *$ & -2.601 & $-5.104 * *$ & -3.504 \\
\hline \multirow{2}{*}{$\ln ($ LiveS $)$} & $\mathrm{I}(0)$ & $-3.379 * *$ & -2.930 & $-3.802 * *$ & -3.500 \\
\hline & $\mathrm{I}(1)$ & $-4.379 * *$ & -2.601 & $-4.585 * *$ & -3.504 \\
\hline \multirow{2}{*}{$\ln (\mathrm{FiSh})$} & $\mathrm{I}(0)$ & $-3.861 * *$ & -2.930 & $-3.837 * *$ & -3.500 \\
\hline & $\mathrm{I}(1)$ & $-3.696 * *$ & -2.601 & $-3.969 * *$ & -3.504 \\
\hline \multirow{2}{*}{$\ln (\mathrm{FoR})$} & $\mathrm{I}(0)$ & -2.349 & -2.930 & $3.749 * *$ & -3.500 \\
\hline & $\mathrm{I}(1)$ & $-4.448 * *$ & -2.601 & $-4.702 * *$ & -3.504 \\
\hline
\end{tabular}

Table 2. ADF Unit Root Test for log Variables.

**Significant and Stationary at $0.05 \%$ Critical Value

Note: $\mathrm{I}(0)=$ Level; $\mathrm{I}(1)=$ First Difference; All unit roots are specified by AIC at lag one. 
Since the series are stationary at level $\mathrm{I}(0)$ and first differencing $\mathrm{I}(\mathrm{I})$ and that none of the variables are stationary at second order differencing I(2), this mixed data integration properties confirmed that the ARDL Bound Cointegration approach is the appropriate technique to be employ in this study [11]. Table 3 presents the lag order selection criteria for
ARDL Model. The result indicates five lag selection criteria were used to determine the optimal maximum lag lengths in the sequence of Likelihood Ratio Test Statistics (LR), Final Prediction Error (FPE), Akaike Information Criterion (AIC), Schwarz Information Criterion (SIC) and Hennan-Quinn Information Criterion (HQIC).

Table 3. Lag order Selection Criteria for the ARDL Model.

\begin{tabular}{lllllll}
\hline Model & Lag & LR & FPE & AIC & HQIC \\
\hline \multirow{4}{*}{ Model } & 0 & & $5.20 \mathrm{E}-17$ & -23.3131 & -23.2394 & -23.1181 \\
& 1 & 799.7 & $8.60 \mathrm{E}-24$ & -38.9317 & -38.4898 \\
& 2 & 394.78 & $6.70 \mathrm{E}-27$ & -46.1147 & -45.3045 \\
& 3 & 87.898 & $3.3 \mathrm{e}-27^{*}$ & $-46.9369^{*}$ & -45.7257 \\
\\
\hline
\end{tabular}

Asterisk (*) indicates lag order selected by one of the Criterion

The results indicate the optimal lag length(s) was three out of a maximum number of four lags specified. The selection was based on the minimum value specified by the five different criteria. AIC is known to be selected with lower lagged values in the model than any of the other criteria. Given the stationarity test and the selection of three optimal maximum lags for the model, ARDL was fitted to assess the relationship between the study variables.
The ARDL cointegration test for this model was performed for five regressors with a lag length of three specified by the Akaike Information Criterion (AIC). The critical values were taken from [16] at 5 percent significance level with an unrestricted intercept and no trend equation. Table 4 presents the ARDL bound test for cointegration of model.

Table 4. ARDL Bound Test for Cointegration Results.

\begin{tabular}{llll}
\hline \multirow{2}{*}{ Estimated Model } & \multirow{2}{*}{ F-Statistics } & Critical Value & \\
\cline { 2 - 4 } & & Lower Bound I(0) & Upper Bound I(1) \\
\hline $\mathrm{F}(\ln R G D P / \operatorname{lnCoP} \ln L i v e S \ln F i S h \ln F o R)$ & $8.278^{* *}$ & 2.86 & 4.01 \\
\hline
\end{tabular}

Notes: ** Statistical significance at $0.05 \%$ level

The results in Table 4 show a calculated F-statistic (8.278) value higher than the upper critical bound value (4.01) at 5 percent level of significance. This implies that the null hypothesis of non-cointegration could be rejected for all variables in the model. Thus, the result suggests that a longrun relationship exists between agriculture sub-sectors and economic growth. The nature of the relationships could be investigated via the analysis of estimated parameters from the
ARDL-Error Correction Model regression.

Table 5 presents the estimated long run conditional ARDLerror correction model for economic growth and agriculture sub-sectors of The Gambia. The result was generated from the first equation of the co-integrating $\operatorname{ARDL}(3,2,2,1,0)$ model. The estimated variables of long run relationship by reveals the contribution of crops, livestock, fisheries and forestry sub-sectors to economic growth of The Gambia.

Table 5. Estimated Long-run Multipliers.

\begin{tabular}{|c|c|c|c|c|}
\hline \multicolumn{5}{|c|}{ Dependent Variable: InRGDP } \\
\hline \multicolumn{5}{|c|}{ ARLD $(3,2,2,1,0)$ Selected based on AIC } \\
\hline Regressor & Coefficient & Standard. Error & t-Statistics & P-Value \\
\hline $\operatorname{lnCoP}$ & $0.1162 * *$ & 0.0170 & 6.83 & 0.000 \\
\hline lnLiveS & 0.0301 & 0.3695 & 0.08 & 0.935 \\
\hline $\operatorname{lnFiSh}$ & $0.4923 * *$ & 0.1737 & 2.83 & 0.008 \\
\hline $\operatorname{lnFoR}$ & 0.2171 & 0.2268 & 0.96 & 0.345 \\
\hline Constant & $0.3828 * *$ & 0.0874 & 4.38 & 0.000 \\
\hline
\end{tabular}

Notes: $* *$, denote significance level at $0.05 \%$.

The result of the estimated coefficients of the long run relationship in Table 5 indicates that crops sub-sector has a positive and significant influence on economic growth of The Gambia at 5 percent level. The estimated coefficient of crops implies that 1 percent increase in crops sub-sector will increase economic growth by approximately 0.12 percent, all things being equal. This is in line with the result of [17] whereas this contradicts with the finding of [18] who found crops sub-sector to be insignificant to Zanzibar's economic growth in the long-run.

Livestock sub-sector exhibit insignificant positive relationship with economic growth. The findings indicate that livestock sub-sector does not have substantial significant effect to the economic growth of The Gambia in the long-run. The finding contradicts the evidence from the study of $[17$, 18] who both found the sub-sector to be positive significant 
with growth. The insignificant effect of livestock sub-sector might be attributed to several factors but most especially to the little attention placed by government to revitalize the subsector.

Fisheries sub-sector exhibit a positive relationship with economic growth in the long run. The coefficient indicates that a 1 percent rise in the RGDP of fisheries leads to an increase in economic growth by 0.49 percent in the long run ceteris paribus. The significant effect implies that the subsector can help boost economic growth of The Gambia. The long-run positive influence of the fisheries sub-sector could be attributed to the natural endowment of The Gambia to the mouth of the Atlantic Ocean and the navigability of the sea for fishing and activities related to fishing. This gives evidence to the potential contribution of fisheries sub-sector in the economic growth process in the long-run. On the other hand, Forestry sub-sector was found to be positively but statistically insignificant to economic growth in the long-run. This result implies that the sub-sector does not have substantial significant effect on economic growth of The Gambia in the long-run.

Table 6 presents the constructed Error Correction Model (ECM) result for the ARDL $(3,2,2,1,0)$ model. The main aim was to capture the short-run dynamics of the model. The outstanding feature of this model is the inclusion of a one period lagged error term (ECT-1). The 1-period lag error term is a residual of the co-integrating vector between economic growth and agriculture sub-sectors of the model. The estimated coefficient of the ECT indicates the speed of restoring the equilibrium in the long-run after experiencing a shock in the economy.

Results from Table 6 shows a negative error correction term with a highly statistically significant at level 5 percent level of significant. The coefficient of the $\mathrm{ECT}_{-1}$, suggests that 17 percent of disequilibria from the previous quarters' shock converge back to the long-run equilibrium in the current quarter. In this case, the findings indicate that the speed of adjustment is slow and will take some time for the system to get back to the long-run equilibrium after a shortrun shock. The ECT for this model gave evidence to reject the null hypothesis that the short-run coefficients are all equal to zero against the alternative hypothesis that assumes at least one coefficient differs from zero.

Table 6 shows the results for the coefficients of all shortrun dynamic multipliers of the model. The coefficients exhibit different signs unlike what was revealed in the long run. Results from Table 6 reveal that the second lagged period of RGDP of The Gambia will be able to predict itself in the short-run. On the contrary the third lagged period of RGDP indicates inability to predict itself. The estimated cointegrated $\mathrm{ECM}$ equation of the $\operatorname{ARDL}(3,2,2,1,0)$ Model exhibit only the significant coefficients.

Table 6. Estimated Short-run Dynamics.

\begin{tabular}{|c|c|c|c|c|}
\hline \multicolumn{5}{|l|}{ Dependent Variable: $\Delta$ InRGDP } \\
\hline \multicolumn{5}{|l|}{ ARLD $(3,2,2,1,0)$ Selected based on AIC } \\
\hline Regressor & Coefficient & Standard Error & t-Statistics & P-Value \\
\hline Constant & $0.3828 * *$ & 0.0874 & 4.38 & 0.000 \\
\hline ECT-1 & $-0.1720 * *$ & 0.3617 & -4.76 & 0.000 \\
\hline$\Delta \operatorname{lnRGDP}(-2)$ & $0.7795 * *$ & 0.1862 & 4.19 & 0.000 \\
\hline$\Delta \operatorname{lnRGDP}(-3)$ & -0.0411 & 0.0260 & -1.58 & 0.122 \\
\hline$\Delta \ln \mathrm{CoP}(-1)$ & $0.1045 * *$ & 0.0148 & 7.04 & 0.000 \\
\hline$\Delta \operatorname{lnLiveS}(-1)$ & $0.5139 * *$ & 0.0700 & 7.34 & 0.000 \\
\hline$\Delta \operatorname{lnLiveS}(-2)$ & $-0.4286 * *$ & 0.1316 & -3.26 & 0.002 \\
\hline$\Delta \operatorname{lnFiSh}(-1)$ & -0.0578 & 0.0757 & -0.076 & 0.449 \\
\hline \multicolumn{5}{|l|}{ F-Statistics $23306.91 * *$ Prob(F-statistic) 0.000} \\
\hline \multicolumn{5}{|l|}{$\mathrm{R}^{\wedge} 20.9972$} \\
\hline Adjusted R^2 0.9962 Durbin-Watson 1.293983 & & & & \\
\hline
\end{tabular}

Notes: **, denote significance level $0.05 \%$

The result for the first lag of crops sub-sector relate positively and significantly in its contribution to economic growth of The Gambia in the short run. The coefficient implies that a 1 percent rise in the RGDP of crops sub-sector will lead to an increase of 0.1 percent in economic growth per quarter in the short run ceteris paribus. However, the results of the second lagged value demonstrate a negative but significant relationship with economic growth in the short run. The estimated coefficient implies that a 1 percent rise in the second lagged period of crops sub-sector's will lead to a decrease of about 0.10 percent to economic growth of The Gambia in the short-run ceteris paribus. This result concurs with the result of [18] who found crops sub-sector of Zanzibar to relate positively with economic growth in the short-run.

The result shows a positive and significant relationship between first lagged period of Livestock and economic growth of The Gambia. The livestock sub-sector demonstrates high effect with indicating that a 1 percent rise in the first lag of livestock will lead to an increase of about 0.51 percent in economic growth in the short run ceteris paribus. Conversely, result of the second lagged period of the livestock sub-sector differs with a negative effect. This implies that in the short-run, a $1 \%$ increase in RGDP of livestock sub-sector will lead to a decline of about $0.42 \%$ in economic growth on average ceteris paribus.

Fisheries sub-sector shows a completely dissimilar result as compared to its long run result. The sub-sector in the first 
lag was negative and statistically insignificant. This findings postulate that when all other things remain constant, the first lag of fisheries sub-sector will not contribute to economic growth of The Gambia in the short run. This conforms to the findings of [19] who found insignificant effect of fisheries to economic growth. This finding is due to the fact that domestic fisheries activities remain low as a result of underdevelopment in the sub-sector, while at the same time overexploitation of demersal stocks, to a large extent owing to the activities of foreign trawlers, and have become an issue of concern.

Table 7 presents results of short run Granger causality tests for the Model. The results reveal a unidirectional causality between livestock and economic growth as well as between fisheries and economic growth of The Gambia. The direction of causality runs from economic growth to livestock subsectors. This result conforms to the finding of [18] whose study found economic growth to Granger cause livestock sub-sector of Zanzibar. Similarly, the same direction is observed from economic growth to fisheries sub-sector in the short-run. This implies that adjustment in the economy causes both livestock and fisheries sub-sectors to change in the short-run. It is also remarkable to note that economic growth of The Gambia underlines the importance of both livestock and fisheries sub-sectors. It can be seen that economic growth does not Granger cause crops and forestry sub-sectors of The Gambia in the short-run.

Livestock sub-sector reveal unidirectional causality between forestry. The result provides evidence for causality running from livestock to forestry. This implies that any change in livestock sub-sector would cause change in forestry sub-sector in the short-run. Result also reveals no significant Granger causality between livestock sub-sector and economic growth and fisheries sub-sector in the short-run.

Table 7. Short-run Granger Causality Test.

\begin{tabular}{|c|c|c|c|c|c|c|c|}
\hline Equation & Source of cat & tion (Indep & ent variable & in the short & & & \\
\hline Dependent variable & D(InRGDP) & $\mathrm{D}$ (inCoP) & D(InLiveS) & D(InFiSh) & D(InFoR) & All & Direction of causality \\
\hline $\mathrm{D}(\ln R G D P)$ & & $\begin{array}{l}{[2.5532]} \\
(-0.466)\end{array}$ & $\begin{array}{l}{[14.058]} \\
(0.003 * *)\end{array}$ & $\begin{array}{l}{[10.058]} \\
(0.014 * *)\end{array}$ & $\begin{array}{l}{[6.5484]} \\
(-0.088)\end{array}$ & $\begin{array}{l}{[37.916]} \\
(0.000 * *)\end{array}$ & $\begin{array}{l}\text { RGDP } \rightarrow \text { Livestock } \\
\text { RGDP } \rightarrow \text { Livestock } \rightarrow \text { Fisheries } \\
\text { RGDP } \rightarrow \text { All }\end{array}$ \\
\hline $\mathrm{D}(\mathrm{inCoP})$ & $\begin{array}{l}{[6.2251]} \\
(-0.101)\end{array}$ & & $\begin{array}{l}{[2.2897]} \\
(-0.515)\end{array}$ & $\begin{array}{l}{[20.751]} \\
(0.000 * *)\end{array}$ & $\begin{array}{l}{[1.0472]} \\
(-0.79)\end{array}$ & $\begin{array}{l}{[39.863]} \\
(0.000 * *)\end{array}$ & $\begin{array}{l}\text { Crop } \rightarrow \text { Fisheries } \\
\text { Crop } \rightarrow \text { All }\end{array}$ \\
\hline $\mathrm{D}(\ln$ LiveS $)$ & $\begin{array}{l}{[5.8118]} \\
(-0.121)\end{array}$ & $\begin{array}{l}{[7.8833]} \\
(0.048 * *)\end{array}$ & & $\begin{array}{l}{[4.0604]} \\
(-0.255)\end{array}$ & $\begin{array}{l}{[10.989]} \\
(0.012 * *)\end{array}$ & $\begin{array}{l}{[36.107]} \\
(0.000 * *)\end{array}$ & $\begin{array}{l}\text { Livestock } \rightarrow \text { Crop } \\
\text { Livestock } \rightarrow \text { Forestry } \\
\text { Livestock } \rightarrow \text { All }\end{array}$ \\
\hline $\mathrm{D}(\ln \mathrm{FiSh})$ & $\begin{array}{l}{[5.9923]} \\
(-0.112)\end{array}$ & $\begin{array}{l}{[7.7755]} \\
(-0.051)\end{array}$ & $\begin{array}{l}{[18.487]} \\
(0.000 * *)\end{array}$ & & $\begin{array}{l}{[10.429]} \\
\left(0.015^{* *}\right)\end{array}$ & $\begin{array}{l}{[31.787]} \\
(0.001 * *)\end{array}$ & $\begin{array}{l}\text { Fisheries } \rightarrow \text { Livestock } \\
\text { Fisheries } \rightarrow \text { Forestry } \\
\text { Fisheries } \rightarrow \text { All }\end{array}$ \\
\hline $\mathrm{D}(\ln \mathrm{FoR})$ & $\begin{array}{l}{[1.9515]} \\
(-0.583)\end{array}$ & $\begin{array}{l}{[3.8339]} \\
(-0.28)\end{array}$ & $\begin{array}{l}{[5.732]} \\
(-0.125)\end{array}$ & $\begin{array}{l}{[2.0292]} \\
(-0.566)\end{array}$ & & $\begin{array}{l}{[20.228]} \\
(-0.063)\end{array}$ & \\
\hline
\end{tabular}

[ ] $\chi^{2},(* *)$ Probability of $\chi^{2}$ denote statistical significance at the $0.05 \%$ level

The result in Table 7 confirms no significant Granger causality from crops to economic growth, livestock and forestry sub-sectors of The Gambia. Furthermore, the results show a joint significance Granger causality running from economic growth to crops, livestock, fisheries and forestry sub-sectors of The Gambia. This implies that economic growth of The Gambia Granger causes agriculture subsectors jointly in the short-run. The result also shows that all other equations jointly Granger causes each other with the exception of forestry sub-sector. This indicates there is shortrun Granger causality running from all variables jointly with the exception of forestry sub-sector which did not Granger cause with any of the other sub-sectors in the short-run.

Table 8 displayed the results of diagnostics tests for Model. The results show that the Breusch-Godfrey Serial Correlation test was insignificant for all lags in the model. This provide evidence to fail to reject the null hypothesis that the model does not suffer from serial correlation problem. The results indicate that the heteroscedasticity does not exist. Therefore, the variance of the error term of the model is constant (homoskedastic) and that the model was not misspecified. Furthermore, the Ramsery test was not statistics significant at $5 \%$ level of significance. This indicate there is no misspecification of the model.

Table 8. Diagnostic Test Results for the Model.

\begin{tabular}{ll}
\hline Diagnostic Test & F-statistics (p-value) \\
\hline Breusch-Godfrey Serial Correlation test & $0.8405(0.4824)$ \\
Breusch-Pagan test for Heteroskedasticity & $1.7666(0.0850)$ \\
Ramsey test for Model Specification & $2.020388(0.1649)$ \\
\hline
\end{tabular}

F-Statistics; P-Value in Parenthesis

Figures 1 and 2 plots the CUSUM and CUSUMQ statistics for Model. The results generally indicate absence of any instability of the coefficients during the study period since the plots of the two statistics are confined within the $5 \%$ critical bounds.

Limitations

The study attempted to obtain data on value added of the variables for an extended sample period (1986-2016) from The Gambia Bureau of Statistics (GBoS). This was impossible due to unavailability of data on some of the study variables for some period. Therefore, the study relied on time-series of RGDP of the variables as a substitute or proxy for the variables used. The series were available in different base years which require some back casting techniques to 
convey them to a single base year. Therefore, having a complete data set on value added of the variables and on a single base from GBoS could have enriched the output and provided better authenticated findings.

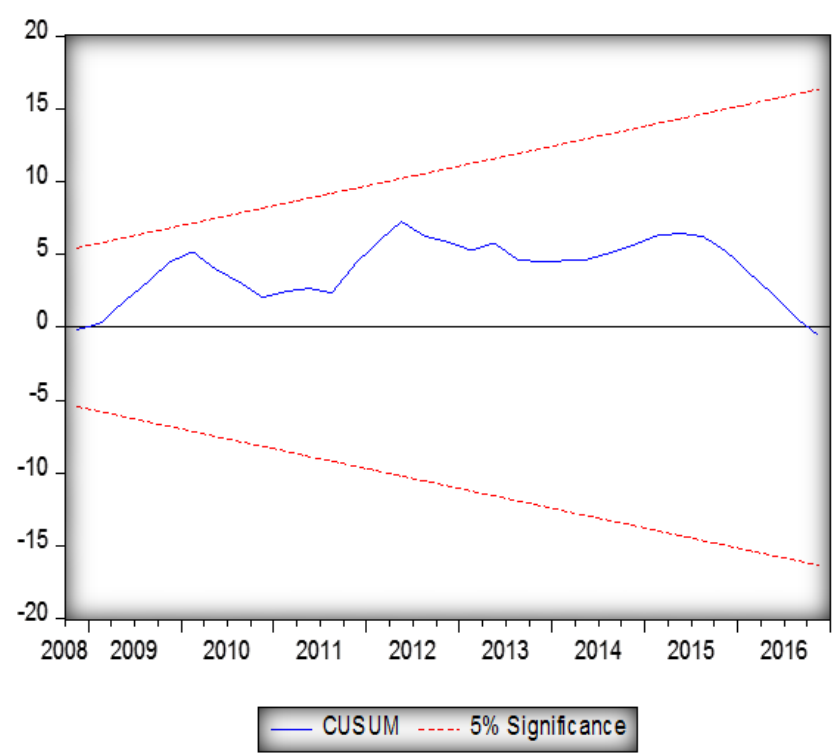

Figure 1. Cusum plot for Model 1.

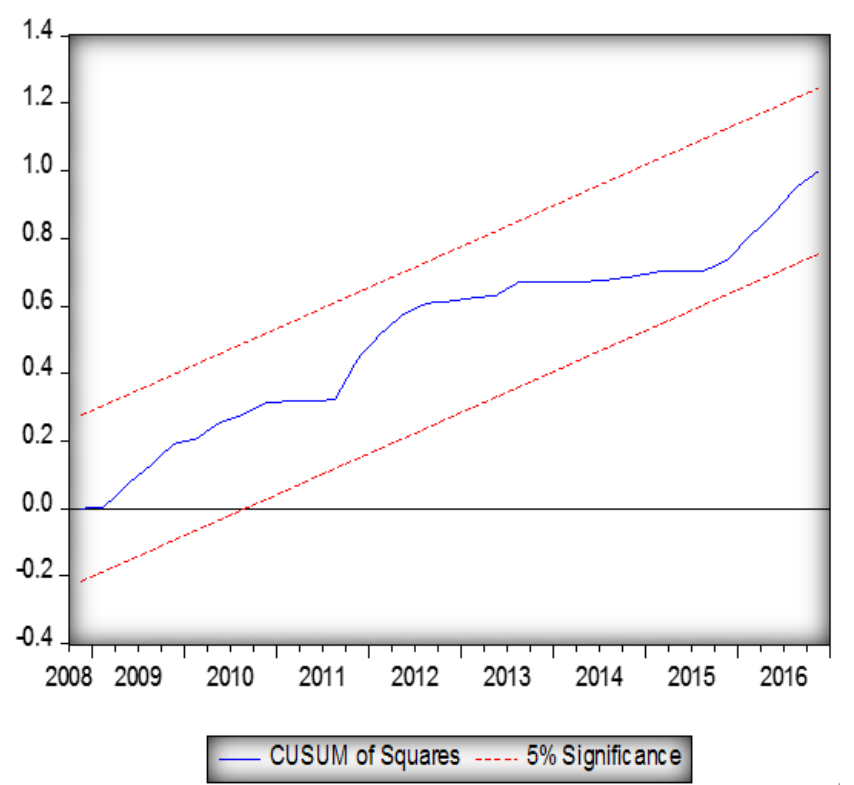

Figure 2. Cusum Squares plot for Model 1.

\section{Conclusion}

Agriculture sub-sectors influence economic growth of The Gambia positively and significantly over the sample period. Therefore, the Government of The Gambia should apply the vertically integrated approach in order to balance out the lopsided nature of the sector most especially with the crop sub-sector that contributed more percent to the economic growth. Agriculture policy formulated and implemented by Government should focus much more on agriculture subsectors (crops, livestock, fisheries and forestry) as the major contributors to the economic growth. In that vein, the
Government of The Gambia should make some key important interventions in the agricultural sub-sectors by introducing innovative agriculture technologies that could improve productivity of the sub-sectors.

\section{References}

[1] Kemisola, C. (2014). Government Expenditure on Agriculture and Economic Growth in Nigeria.

[2] Satyal, V. R. (2013). African agriculture, transformation and outlook. NEPAD (New Partnership for African Development) 11 .

[3] World Bank (2011). Global Strategy to Improve Agricultural and Rural Statistics. Economic and sector work.

[4] OECD-FAO (2016). Agriculture in Sub-Saharan Africa: Prospects and challenges for the next decade. https://dx.doi.org/10.1787/agr_outlook-2016-5-en.

[5] FAO (2002). The Role of Agriculture in the Development of Least-developed Countries and their Integration into the World Economy. Fao.

[6] Awokuse, T. O. (2009). Does agriculture really matter for eonomic growth in developing countries? Am. Agric. Econ. Assoc. Annu. Meet. 26-28.

[7] World Bank (2016). World Development Indicators. https://databank.worldbank.org/source/world-developmentindicators.

[8] The Gambia Bureau of Statistics (2019). Economic indicators. https://www.gbosdata.org/about-us.

[9] The Gambia Bureau of Statistics (2013). The Gambia 2013 Population and Housing Census Preliminary Results. Gambia Bur. Stat. 23.

[10] Gibba, A. \& Molnar, J. A. (2016). Study on exports as a determinant of economic. Some Stud. Econ. Chang. ISBN 97880-89691-27-2 237-244.

[11] Nkoro, E., \& Uko, A. K. (2016). Autoregressive Distributed Lag (ARDL) Cointegration Technique: Application And Interpretation. J. Stat. Econom. Methods 5, 63-91.

[12] Al-Malkawi, H.-A. N., Marashdeh, H. a. \& Abdullah, N (2012). Financial Development and Economic Growth in the UAE: Empirical Assessment Using ARDL Approach to Cointegration. Int. J. Econ. Financ. 4, 105-115.

[13] Khim, V., \& Liew, S. (2004). Which Lag Length Selection Criteria Should We Employ? Univ. Putra Malaysia Econ. Bull. 3, 1-9.

[14] Tursoy, F. (2014). Causality between stock price and GDP in Turkey: An ARDL Bounds testing approach. Energy Econ. Lett. 9, 25-31.

[15] Engle, R. F. \& Granger, C. W. J. (1987). Co-Integration and Error Correction: Representation, Estimation, and Testing. Econometrica 55, 251-276.

[16] Brown R. L, Durbin J \& Evans J. M. (1975). Techniques for Testing the Constancy of Regression Relationships over Time Series B (Methodological). J. R. Stat. Soc. 37, 149-192. 
[17] Chongela, J.(2015). Contribution of Agriculture Sector to the Tanzanian Economy. Am. J. Res. Commun. 3, 57-70.

[18] Shoka, I. H. (2015). Contribution of Agriculture To the Economic Growth of Zanzibar Contribution of Agriculture To the Economic. Masters Thesis, Mzumbe University.

[19] Raza S. A \& Yasir A. F. M. (2010). Role of Agriculture in Economic Growth of Pakistan. Int. Res. J. Financ. Econ.
[20] Chandio, A. A., Yuansheng, J., \& Magsi, H. (2016). Agricultural Sub-Sectors Performance: An Analysis of SectorWise Share in Agriculture GDP of Pakistan. International Journal of Economics and Finance, 8 (2), 156. https://doi.org/10.5539/ijef.v8n2p156 